\title{
Exoskeletal architecture, hypostomal morphology and mode of life of Silurian and Lower Devonian dalmanitid trilobites
}

\author{
PETR BUdIL, ALAN TREVOR THOMAS \& FRANTIŠEK HÖRBINGER
}

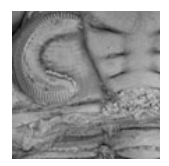

\begin{abstract}
The overall exoskeletal architecture and hypostomal morphology of Silurian Dalmanites and Lower Devonian Odontochile, Reussiana and Zlichovaspis are compared and discussed. All four genera were benthic. However, a gradual shift from predator-scavenger to a scavenging feeding habit is inferred from the evolution of these dalmanitids in the Upper Silurian and Lower Devonian. In the more conservative, probable predator-scavenger Dalmanites, the posterior hypostomal doublure has a group of robust denticles: these would have been effective shredding structures, enabling milling or cutting of food into smaller particles, and allowing Dalmanites to deal with mechanically relatively robust prey. Lower Devonian dalmanitids from the Prague Basin possess a comparable denticulate structure on the posterior hypostomal doublure. However, although overall exoskeletal dimensions are larger, the denticles are significantly finer and denser. The whole exoskeleton of these younger dalmanitids, with a large multi-segmented pygidium, is considered well adapted for close approximation to the sediment surface. Shallow burrowing in a soft substrate, and scavenging with opportunistic predation, is therefore considered to be their main feeding habit. Odontochile, Reussiana and Zlichovaspis characteristically occur in micritic limestone facies, where the sediment surface is likely to have been soft. The shift from a more predatory to a dominantly scavenging mode of life may have occurred independently in several unrelated dalmanitid groups, with "odontochilid" characteristics developing at different stratigraphical levels. • Key words: Dalmanitidae, trilobite, mode of life, body morphology, hypostomes.
\end{abstract}

BudiL, P., THOMAS, A.T. \& HÖRBINGER, F. 2008. Exoskeletal architecture, hypostomal morphology and mode of life of Silurian and Lower Devonian dalmanitid trilobites. Bulletin of Geosciences 83(1), 1-10 (5 figures). Czech Geological Survey, Prague. ISSN 1214-1119. Manuscript received August 23, 2007; accepted in revised form December 4, 2007; issued March 31, 2008.

Petr Budil, Czech Geological Survey, Klárov 3, 11821 Praha 1, Czech Republic; budil@cgu.cz•Alan Trevor Thomas, Earth Sciences (GEES), University of Birmingham, Edgbaston, Birmingham, B15 2TT, United Kingdom; a.t.thomas@bham.ac.uk - Frantisek Hörbinger, Ke Zdravotnímu středisku 120, 15500 Praha 5, Czech Republic; Frantisek.Hörbinger@cuzk.cz.

Dalmanitids form an important part of the trilobite faunas found in Silurian and Lower Devonian carbonate and fine clastic sequences in Avalonia, Kazakh terranes, Australia and Laurentia. After significant late Ordovician extinctions, they occur in early Silurian strata (e.g., El Chair et al. 1985, Curtis \& Lane 1997) albeit relatively rarely, but their acme started in middle Silurian times. In the late Lochkovian and earliest Pragian, they are found widely in the northern peri-Gondwana realm (see Budil et al. submitted). Silurian and Devonian dalmanitids show an evolutionary tendency toward forms with large, multi-segmented and flat pygidia. This morphological shift is associated with increased cephalic convexity (see Campbell 1977), increased genal spine length, and by the changes in hypostomal morphology described below. Discussion of these changes, and assessment of their importance for changes in mode of life, is the focus of this contribution.

Figured and cited specimens are housed in the following institutions: National Museum, Prague (NM), Czech
Geological Survey (CGS), Museum of Comparative Zoology, Harvard University, Cambridge, Massachusetts (MCZ), Natural History Museum, London (NHM) and Lapworth Museum, University of Birmingham (BU).

\section{Systematic palaeontology}

Order Phacopida Salter, 1864

Suborder Phacopina Struve in Richter et al., 1959

Superfamily Dalmanitoidea Vogdes, 1890

Family Dalmanitidae Vogdes, 1890

\section{Genus Dalmanites Barrande, 1852}

Type species. - Trilobus caudatus Brünnich, 1781, from the Coalbrookdale Formation (Wenlock) of England. 

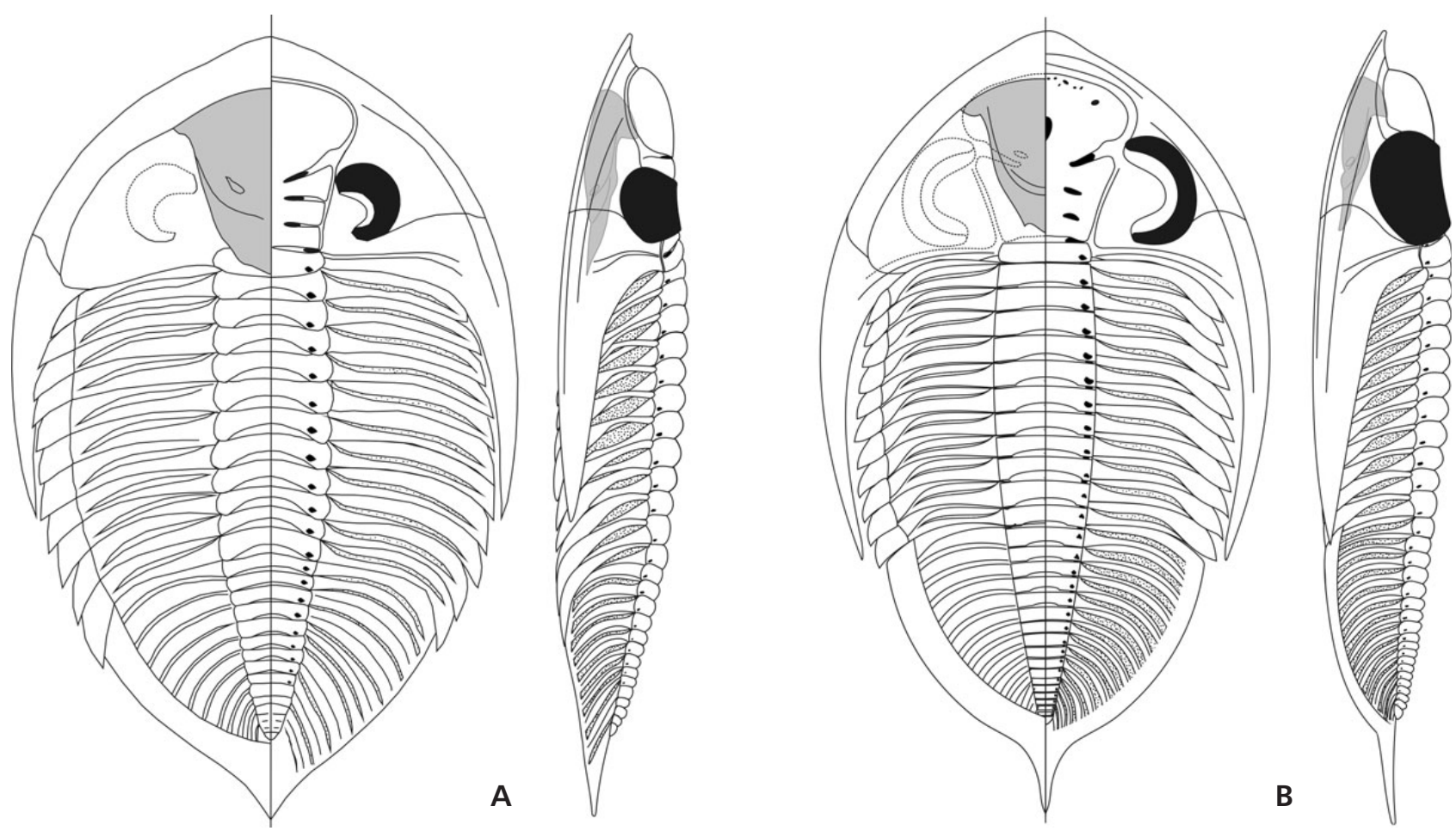

Figure 1. A - schematic drawing of the ventral, dorsal and lateral general body morphology of Dalmanites Barrande, 1852, based on NHM It20991, Dalmanites myops (König, 1825), Silurian, Wenlock, Much Wenlock Limestone, Dudley. • B - sketch of the dorsal and ventral general body morphology in Zlichovaspis Přibyl \& Vaněk, 1972 (after Budil et al. in press). The inferred position of the hypostome is indicated.

Remarks. - The British Wenlock species of Dalmanites have not been revised in detail since they were originally described in the nineteenth and early twentieth centuries: there has been some taxonomic and nomenclatural confusion as a consequence (Dean 1960, Morris 1988). Delo (1935) selected D. caudatus (Brünnich, 1781) as type species of the genus. The same species was later called longicaudatus by Murchison (1839). However, what Brongniart (1822) called caudatus is a different species: it is the same as what Salter (1864) called 'var.' $\alpha$ vulgaris, and which was previously named myops by König (1825). Salter's figures of these taxa remain the best available: his (1864, pl. 3, figs 19-21 and 5) respectively show typical specimens of $D$. caudatus and D. myops. The latter species differs from caudatus most obviously in having only a short anterior mucro on the cephalon, a smaller eye that does not indent the posterior border furrow, a glabella that does not narrow so strongly posteriorly, and a pygidium with only a short posterior spine.

Description. - Exoskeleton ovoid in outline, moderately vaulted. Length/width index approximately 1.5. Cephalon semicircular, with robust genal spines reaching to $7-8^{\text {th }}$ (rarely to $9^{\text {th }}$ ) thoracic segment. Anterior cephalic margin semicircular to parabolic, mucronate or with simple precranial process. Facial suture lying inside or close to preglabellar furrow. Glabella strongly expanding anteriorly. S1 and S2 apodemes deeply incised; no longitudinal glabellar furrow. L1, L2, L3 and LF vaulted. Eye large, lying between S3 and S1 or S0. Doublure wide, with deep and wide pseudovincular (antennal) and shallow vincular furrows perceptible laterally. Hypostome slightly vaulted, posteriorly elongated, subtriangular in outline; three prominent posterior denticles, the median one most prominent.

Short, robust, irregularly arranged spines occur on the posterior hypostomal doublure; in some specimens, they are visible on the posterior hypostome margin in posterior external view. Eleven thoracic segments; pleural furrows post-facetal, deeply impressed, lanceolate in outline. Pleural tips pointed, with wide articulating facets, moderately curved backward at front of thorax but more prominently inclined and shorter (tr.) posteriorly. Pygidium subtriangular, length/width index $0.70-0.74$. Axis vaulted, approximately 0.35 of pygidial width. Twelve to fifteen axial rings. Nine to ten deep and wide pleural furrows, with flat or only slightly concave bottoms, almost reaching pygidial margin; interpleural furrows narrower. Anterior pleural band more vaulted and broader than posterior. Mucro vaulted, prolonged into broad-based spine. Doublure relatively wide, inner flange of posterior part upturned towards dorsal exoskeleton. Sculpture of fine and coarse granules. 

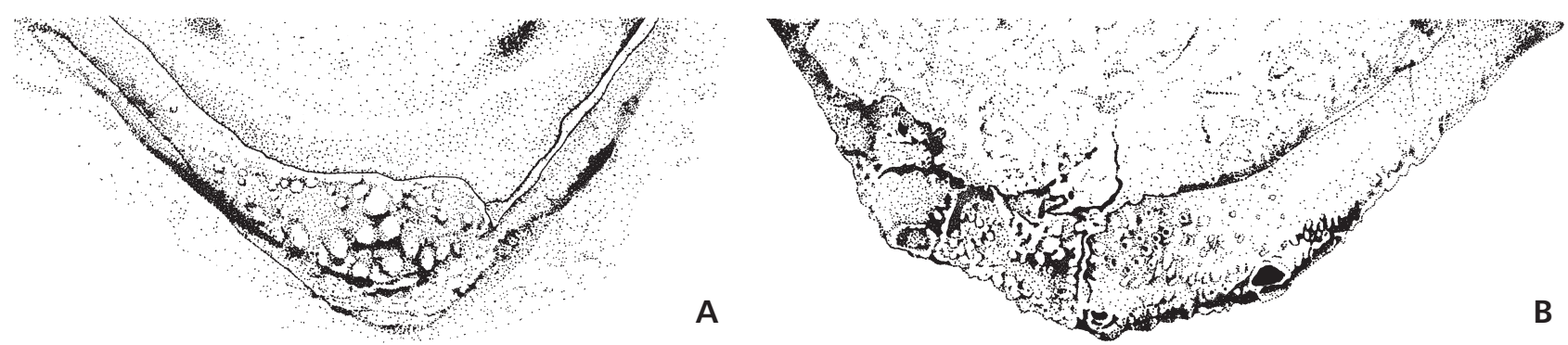

Figure 2. Line drawing of the differences in the spatial distribution of minute denticles on the posterior hypostomal doublures. $\bullet$ A - Dalmanites myops (König, 1825). Silurian, Wenlock, Much Wenlock Limestone Formation, Dudley, BIRUG 3366. • B - Odontochile cristata Hawle \& Corda, 1847. Lower Devonian, Pragian Stage, Praha Fm., Dvorce-Prokop Limestone, Praha-Konvářka, latex cast of the specimen CGS JV 3509.

Remarks. - This general description of typical Dalmanites morphology is based on D. caudatus (Brünnich, 1781), D. myops (König, 1825) and D. corrugatus (Reed, 1901), all from the British Wenlock. These form part of a closely related group of European and North American Wenlock-early Ludlow species (Ramsköld 1985), which also includes D. nexilis Salter, 1864, D. limulurus (Green, 1832), D. obtusus (Lindström, 1885) and D. platycaudatus Weller, 1907. All these share especially prominent lateral nodes on the first, sixth and seventh thoracic axial rings, and nodes on the pygidial pleural ribs (for discussion see also Sandford \& Holloway 2006).

However, there are other species sometimes assigned to Dalmanites, which differ in a variety of ways (Ramsköld 1985). Some were removed from Dalmanites by Campbell (1977) and Holloway (1981). Others were assigned by Curtis \& Lane (1998, pp. 62, 63) to Bessazoon, which is known from the British and Australian Llandovery and Wenlock. In the context of the present study, the relatively large and wide multi-segmented pygidium of Bessazoon, somewhat reminiscent of Lower Devonian dalmanitids, is notable because although unrelated, it shares some of the "odontochilid" features discussed below. There are other early Silurian (e.g., Dalmanites? fezzanensis El Chair, Hammann \& Thiedig, 1985) and late Ordovician dalmanitids (e.g., Eudolatites Delo, 1935 and Mucronaspis Destombes, 1963; see detailed discussion by Lespérance 1975 and Holloway 1981), with comparable morphologies. As well as similar pygidia, these taxa share a generally flat exoskeleton, with moderate to large rather posteriorly positioned eyes, which often form the most elevated part of the exoskeleton.

\section{Genus Odontochile Hawle \& Corda, 1847}

Type species. - Asaphus Hausmanni Brongniart, 1822. Lower Devonian, Pragian Stage, Praha Formation, Dvorce-Prokop Limestone Facies, Turkestanella acuaria Zone.
Description. - Exoskeleton elongate, ovoid in outline, large (maximal sagittal length can exceed $150 \mathrm{~mm}$ ), moderately vaulted. Length/width index approximately 1.6. Cephalon semicircular, with long genal spine extending back to pygidium. Anterior cephalic margin semicircular to parabolic, without anterior process. Facial suture lying outside preglabellar furrow. Glabella strongly expanding anteriorly. S1 and S2 apodemes deeply incised, no longitudinal glabellar furrow. LF vaulted, with distinct median, anterolateral and frontal auxiliary impressions. Eye very large, almost reaching axial furrow at $\gamma$ and posterior border furrow at $\varepsilon$. Palpebral lobe much elevated above glabella. Doublure wide and flat, with deep and wide pseudovincular (antennal) furrow. Hypostome elongated, subtriangular; with three prominent spines posteriorly, and two weaker ones posterolaterally. Robust anterolateral wings. Posterior part of hypostomal doublure vaulted, especially medially, bearing a dense cluster of small denticles. Eleven thoracic segments, with deeply impressed postfacetal pleural furrows lanceolate in outline. Pleural tips pointed, with wide articulating facets, equally curved at front of thorax and at wide (tr.) pygidium. Pygidium large, subtriangular, length/width index 0.70-0.75. Axis vaulted, approximately 0.22 of pygidial width. Sixteen to twenty axial rings; 13-14 deep and wide pleural furrows, with flat or only slightly concave bottom. Interpleural furrows very narrow. Anterior pleural band more vaulted and broader than posterior. Mucro vaulted, generally prolonged into short broad-based spine; in derived species this spine is longer, and more narrowly based. Doublure relatively wide, flat, with inner flange upturned to dorsal exoskeleton. Sculpture of fine and coarse granules.

Remarks. - This brief description of Odontochile morphology is based on the modified diagnosis of Budil et al. (submitted). Reussiana Šnajdr, 1987 strongly resembles Odontochile, but has a very flat exoskeleton, and an exceptionally high number of pygidial segments (17-21 rings and 15-18, possibly 19, wide and flat-bottomed pleural furrows). The pygidium of Reussiana bears only a very short, blunt posterior process, and lacks a posterior spine. 
Odontochile hausmanni (Brongniart, 1822)

$\mathrm{n}=\mathbf{7 0}$

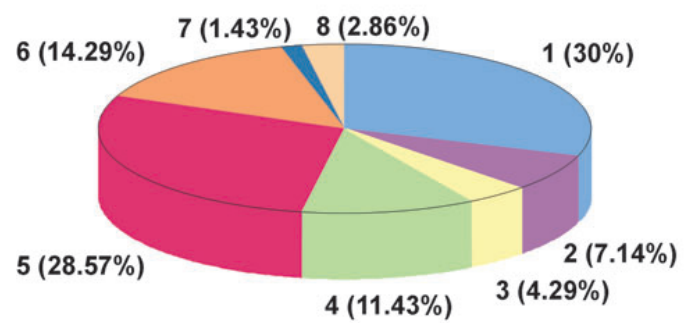

Zlichovaspis (Z.) rugosa rugosa (Hawle \& Corda, 1847)

$\mathrm{n}=\mathbf{6 6}$

$7(3.03 \%) \quad 8(6.06 \%)$

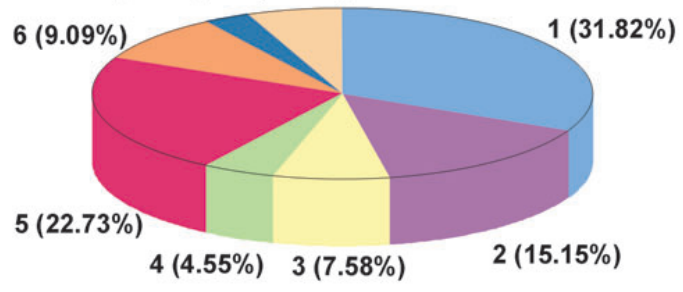

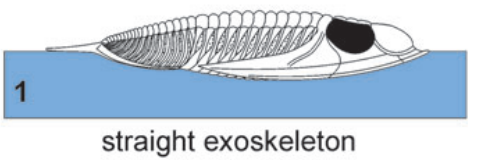

straight exoskeleton

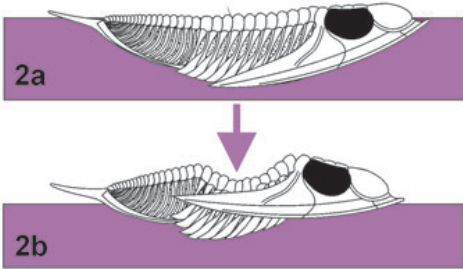

moderately flexed thorax
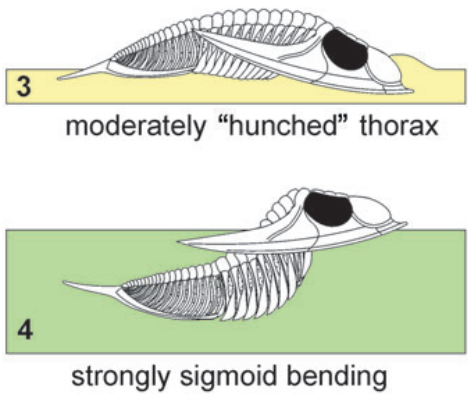

of the thorax

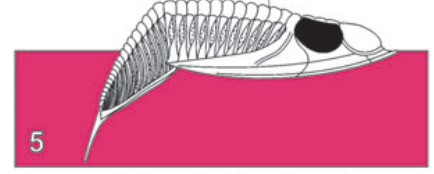

pygidium inclined under at $40-60^{\circ}$ to the horizontal line

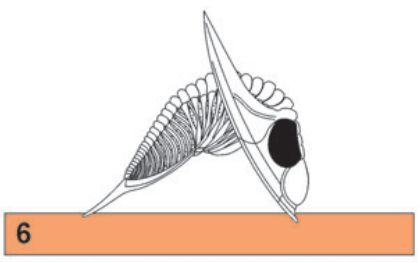

incompletely enrolled specimens
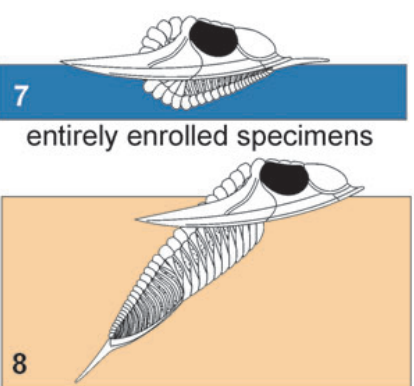

all thorax is inclined

Figure 3. Summary of the main complete exoskeletal configurations in Odontochile hausmanni (Brongniart, 1822) and Zlichovaspis (Zlichovaspis) rugosa rugosa (Hawle \& Corda, 1847).

Zlichovaspis (Zlichovaspis) Přibyl \& Vaněk, 1971 differs from Odontochile particularly in having a subtriangular cephalon with a parabolic anterior margin, and by the presence of a short median process. The pygidium of Zlichovaspis (Zlichovaspis) is more subtriangular in outline, with 16-21 axial rings plus a terminal piece, and with a long terminal spine. Zlichovaspis (Devonodontochile) Šnajdr, 1985 shares these features, but has a more pronounced anterior cephalic process of linguoid outline, a long but narrower terminal pygidial spine with a less robust base, and is especially distinguished by the prominent perforation of all elevated exoskeletal parts by mega- pores. The hypostomes of all these genera are still relatively poorly known, but they seem to share a similar morphology, which differs in several respects from that of Dalmanites (see below).

\section{Remarks on exoskeletal morphology}

The exoskeleton of most Silurian and Devonian dalmanitids is dorsoventrally flattened, but with the axial region (including the glabella) elevated. The ventral side of the exoskeleton is flat, with a relatively wide doublure. The

Figure 4. A-C - Dalmanites myops (König, 1825). Ventral side of hypostome, internal mould with exoskeleton with preserved denticles on posterior doublure, BU 3366. Silurian, Wenlock, Much Wenlock Limestone Formation, Dudley. $\bullet$ A - ventral view, $\times 2$. $\bullet$ B - posterior view, $\times 2$. $\bullet$ - detail of denticles, $\times 3.5$. $・$ D-G - Odontochile cristata Hawle \& Corda, 1847. Latex cast of the hypostome, CGS JV 3509, Lower Devonian, Pragian Stage, Praha Formation, Dvorce-Prokop Limestone, Praha-Konvárka. $\bullet$ D - posteroventral view of hypostomal doublure, $\times 3 . \bullet \mathrm{E}-$ posterolateral view, $\times 2.5$. $\bullet \mathrm{F}$ - ventral view, $\times 1.5$. $\bullet \mathrm{G}-$ oblique ventral view on sculpture of hypostomal margin and maculae, $\times 1.8 \cdot \bullet \mathrm{H}-\mathrm{I}, \mathrm{N}-\mathrm{P}-$ Zlichovaspis $($ Devonodontochile) vigerle (Šnajdr, 1987b). Lower Devonian, Lower Emsian (Zlichovian Regional Stage), Zlíchov Formation, Zlíchov Limestone, Praha-Žvahov. • H - incomplete hypostome CGS JV 3533, internal mould, $\times 1.5$. • I - cephalic doublure, CGS PB 189 (coll. F. Hörbinger), internal mould with relics of exoskeleton, $\times 1 \cdot \bullet \mathrm{N}$ - incomplete hypostome, CGS JV 3523, dorsolateral view showing robust anterolateral wings, $\times 1.5$. $\bullet \mathrm{O}-$ detail of denticles on posterior hypostomal doublure, ex CGS JV 3533, $\times 5 . \bullet P-$ incomplete hypostome, internal mould with relics of exoskeleton, CGS JV $3533, \times 1.5$. - L - Odontochile hausmanni (Brongniart, 1822), neotype, almost complete specimen NM L 15015, lateral view. Lower Devonian, Pragian Stage, Praha Formation, Dvorce-Prokop Limestone, Praha-Dvorce, $\times$ 0.8. • J-K, M - Zlichovaspis (Zlichovaspis) rugosa rugosa (Hawle \& Corda, 1847). Lower Devonian, Pragian Stage, Praha Formation, Dvorce-Prokop Limestone, Damil Hill near Tetín. • J - incomplete cephalic doublure with hypostome in situ, NML 30261, × 1.・K - ditto, MCZ 172840, × 1. $\cdot$ M - almost complete specimen, NML 15001, dorsal view, $\times 1.3$. 
Petr Budil et al. - Morphology and mode of life of Silurian and Lower Devonian dalmanitid trilobites
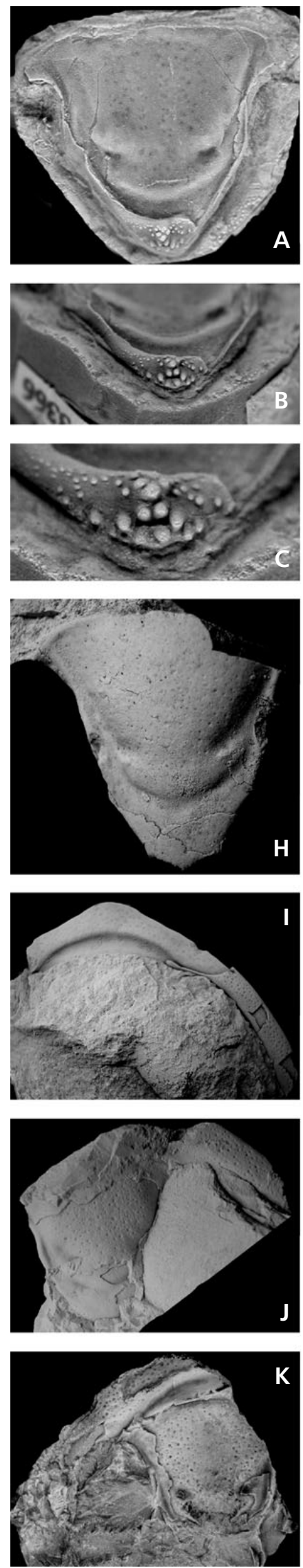
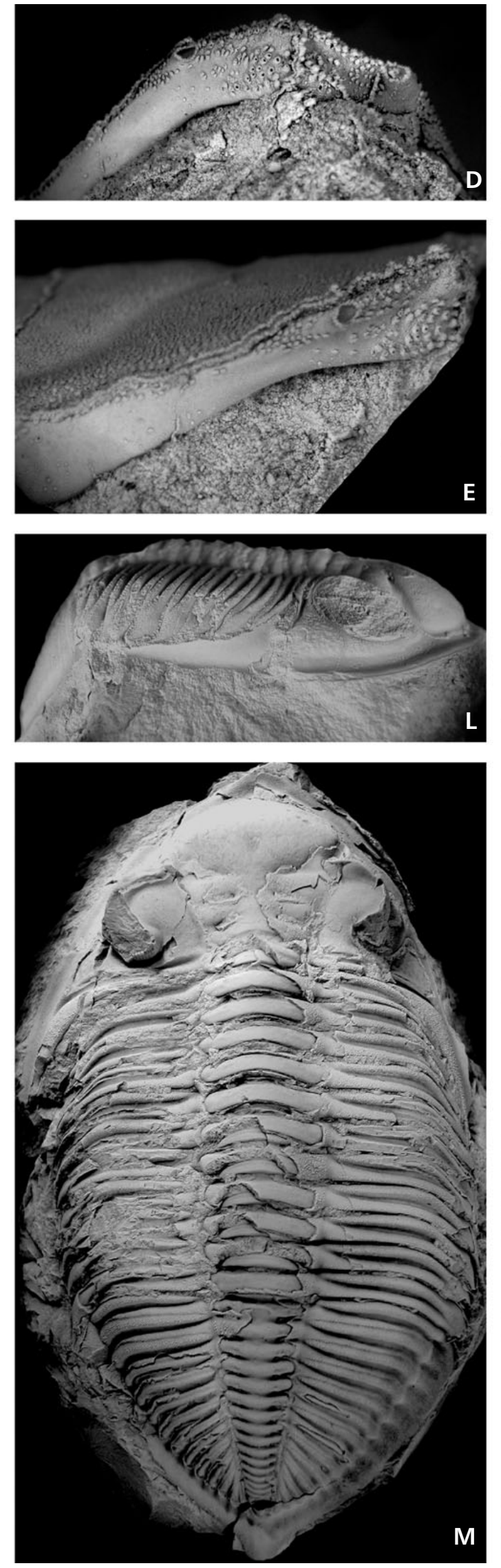
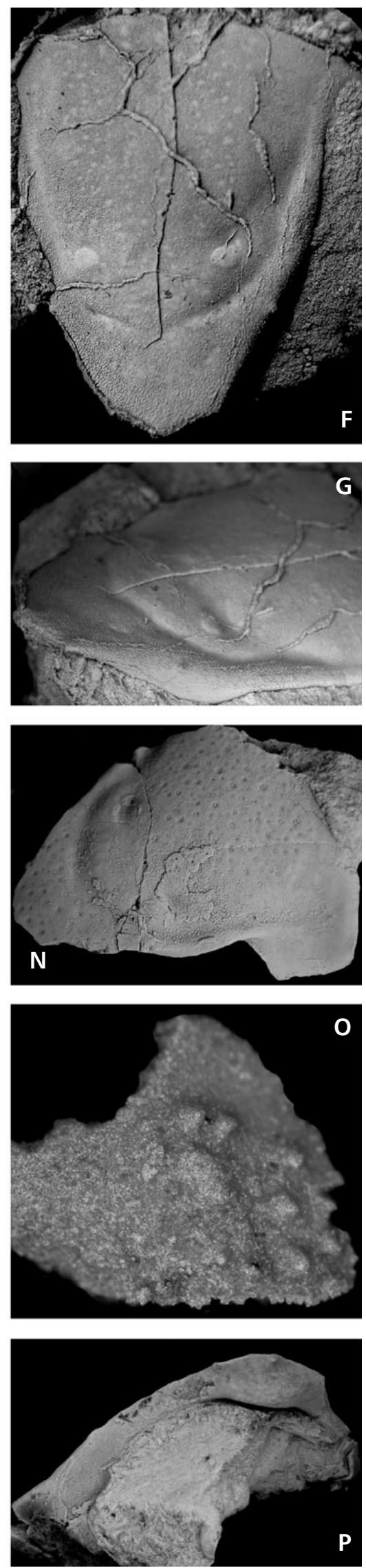
ventral side of the hypostome is wide and relatively flat also, extending only very slightly below the plane of the cephalic doublure or lying at the same level. The prominent, strongly elevated schizochroal eyes with steep visual surfaces contain hundreds of individual lenses, arranged in regular dorso-ventral files. Their field of view is predominantly lateral, being limited anteriorly by the peripheral part of the cheek and by the frontal glabellar lobe. These various characteristics vary in detail between different Silurian and Devonian dalmanitid groups. However, they are generally more pronounced in Odontochile than in Dalmanites, being accompanied in Odontochile by the large, wide, and multi-segmented pygidium. The doublure of Odontochile and Zlichovaspis is prominently pitted: the fine pores probably represent sites of sensor attachment, perhaps comparable with the bothria of arachnids (e.g., Meslinger 1987) and some other arthropod groups. The Lower Devonian Reussiana and Kazachstania Maksimova, 1972 are extreme examples of this morphological type.

General hypostomal architecture is very similar in Dalmanites, Odontochile and Zlichovaspis; no hypostome is known for Reussiana so far. Representatives of these genera share the wide, rounded but elongated subtriangular hypostomal outline, with a moderately vaulted middle body and prominent maculae. The anterolateral wings are very robust (Fig. 4N), suggesting firm attachment of the conterminant hypostome (Fortey \& Owens 1999a, b). The anterior wings probably also developed a small process like that seen in at least some phacopids (see Bruton \& Haas 2003a).

The main differences between the hypostomes of Dalmanites and Odontochile lie in the shape of the posterior and posterolateral margin. In Dalmanites, the general outline of the hypostome is more subtriangular, with three robust posterior spines. By contrast, in Odontochile and Zlichovaspis, the hypostome has a more elongate subpentagonal outline, with three prominent posterior and one pair of additional posterolateral spines. These are seen only in the best preserved specimens however (Fig. 4D; for discussion see Budil et al. submitted). Šnajdr (1987b, p. 14, fig. 2) neither discussed nor figured these features, while Barrande (1852, 1872) overemphasized the prominence of the posterolateral spines.

The major contrast between Dalmanites and Odontochile/Zlichovaspis hypostomes is seen on the posterior doublure (Fig. 2). In all the genera discussed, the medial part of this doublure is vaulted, but this is more distinct in Odontochile and Zlichovaspis (Fig. 4F). In Dalmanites, this part of the doublure possesses a cluster of irregularly arranged short, sparse but relatively robust spines (see Fig. 4A-C). In Odontochile and Zlichovaspis, a comparable structure is developed, but the spines are smaller in size and larger in number. The spines are shorter, denser, narrower in diameter, and their arrangement is more regular (see Fig. 4E-G). Both structures could have functioned in a rasp-like way, shredding, milling and cutting food. Very similar groups of tiny spines on the vaulted median part of the hypostome doublure were found by Bruton \& Haas (2003a, pl. 2, fig. 4-6) in the phacopid Geesops. Broadly comparable structures have been described in some odontopleurids Chatterton \& Perry (1983; see also Fortey \& Owens 1999a, b), in Asaphus (Ivantsov 1990), Isotelus (Fortey \& Owens 1999b) and lichids (see also Kaesler et al. 1997).

Asymmetrically arranged small denticles on the posterior hypostome margin (lying mainly between three larger posterior spines) are visible in external view in some specimens of Dalmanites caudatus (e.g., NHM 59069, BU 56 figured by Salter 1864, pl. 3, fig. 8). In contrast, such structures are very rarely visible in Bohemian Lower Devonian dalmanitids, commonly having been destroyed during preparation from indurated biomicritic limestones. After three years of searching, they have been found only in two specimens briefly discussed also by Budil et al. (submitted). Both specimens were found among specimens coming from soft, white decalcified limestones. The best specimen (Fig. 4D-G) is an almost complete internal and counterpart external mould of a hypostome of Odontochile cristata Hawle \& Corda, 1847 (CGS JV 3509), from the lower part of the Dvorce-Prokop Limestone Facies (Praha Formation, Pragian Stage) from Praha-Konvářka. The rasp-like structure can be seen on a latex cast taken from the external mould. The second specimen is a comparatively poorly preserved fragment of the posterior hypostomal doublure belonging to Zlichovaspis (Devonodontochile) vigerle (Šnajdr, 1987b; CGS JV 3533), found in the decalcified parts of the uppermost Zlichov Limestone from Praha-Žvahov (see Fig. 4H, O-P). Cavities after dissolved fine denticles were seen in the rock matrix surrounding this specimen. However, the whole structure was so fragile that, despite conservation, it was

Figure 5. A, B - Odontochile hausmanni (Brongniart, 1822). Entirely enrolled specimen, a representative of exoskeleton configuration 7 (Fig. 3 ), MCZ 172821. Lower Devonian, Pragian Stage, Praha Formation, Dvorce-Prokop Limestone. Locality unknown. A - dorsal view, B - lateral view. $\times 2.8$. -C - Dalmanites myops (König, 1825). Complete specimen with hypostome in situ, ventral view. NHM It 20991, Silurian, Much Wenlock Limestone., Wenlock, Dudley, $\times$ 0.9. D D E - Zlichovaspis (Zlichovaspis) auriculata (Dalman, 1826), Lower Devonian, Zlichovian regional stage (lower Emsian), Zlíchov Formation, Zlíchov Limestone. Representatives of the exoskeleton configuration 1 (Fig. 3). D - holotype, a nearly complete specimen NML 18728, Karlštejn, internal mould, dorsal view, $\times 1$ 1.7. $•$ E - almost complete, dorsally flattened specimen in shale, NML22577, Praha-Řeporyje, dorsal view, $\times 1.5$. 
Petr Budil et al. - Morphology and mode of life of Silurian and Lower Devonian dalmanitid trilobites
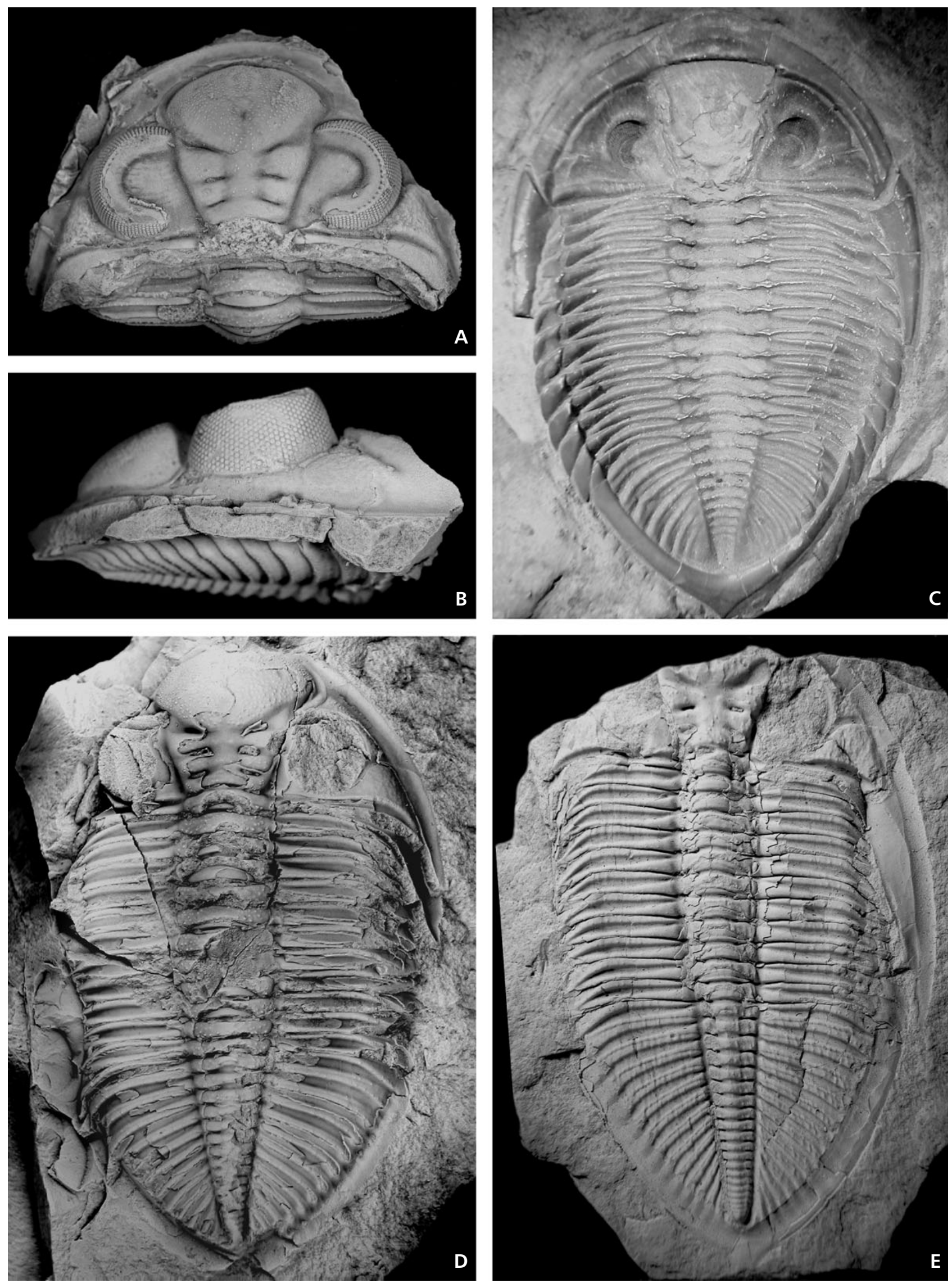
broken during preparation, and only the small fragment figured on Fig. $4 \mathrm{O}$ remained. It comes from the median, most elevated part of the posterior doublure, well seen in Fig. 4P.

\section{Analysis of complete exoskeletons of Lower Devonian dalmanitids from the Prague Basin}

Relatively abundant museum material has been available for this analysis ( $n=144$ complete exoskeletons). Most of the specimens are stored in the National Museum, Prague, but others have been studied in the collections of the Museum of Comparative Zoology, Harvard University, Massachusetts and the Czech Geological Survey. Additional material in several private collections, especially those of the third author, P. Kolár and J. Valíček, has been used also. Only two species - Odontochile hausmanni (Brongniart, 1822) and Zlichovaspis (Zlichovaspis) rugosa rugosa (Hawle \& Corda, 1847) - were sufficiently common to be used; other taxa, especially Zlichovaspis (Zlichovaspis) auriculata (Dalman, 1827), are comparatively little represented. Seventy specimens represent the first species and sixty-six specimens the second (Fig. 3).

Eight main configurations of the articulated exoskeleton have been recognized, but some are rare. Their occurrence ratios are relatively similar in both analysed species, despite their being generically distinct and of different stratigraphical age. A predominance of extended, moderately flexed or "hunched" exoskeletons is as expected (41.43\% in O. hausmani and $54.55 \%$ in Zlichovaspis (Z.) rugosa respectively).

More surprising is the abundance of specimens with the pygidium, or the pygidium and the last few thoracic segments, inclined downwards at approximately $45^{\circ}$ to the horizontal plane (typical example see Fig. 4L; $28.57 \%$ and $22.73 \%$ ). Relatively rare are specimens with a slightly sigmoidally bent thorax (11.43\% and $4.55 \%)$. Conversely, partially enrolled specimens are quite common (14.29\% and $9.09 \%$ ) but only three completely enrolled examples have been found so far (one of Odontochile hausmanni and two of Zlichovaspis (Z.) rugosa rugosa). Similarly, the specimens with straight thorax but with cephalon inclined at some angle are relatively rare $(2.86 \%$ and $6.06 \%$, respectively). Šnajdr (1987b, p. 12) briefly, but largely correctly, discussed the main exoskeleton configurations identified here. He considered the most commonly preserved configurations to represent the pre-mortem attitudes of the animals, partially buried in sediment. We agree with this suggestion with some reservation, because taphonomic processes such as local transport of dead animals by currents could influence the different types of body flexing.
The sampling bias has been usually conceived as an additional factor affecting the analysis. In our case, the selection made by collectors is certainly insignificant, because the articulated remains, particularly of large dalmanitids of Devonian age, are generally very rare in the Barrandian area and they belong to the forefront of every collection. Thus the collection studied represents a relatively good basis for the analysis presented.

Active burrowing by asaphid trilobites, living in comparable lithofacies, was discussed by Cherns et al. (2006). Those authors interpreted Asaphus as the trace-maker of the Thalassinoides ichnofossil, producing limestone "nodules" characterized by Y- and T- shaped branching. The Lower Devonian dalmanitids of the Prague Basin occur in nodular limestones also, but there is no direct proof that the nodules originated in a similar way. The general body morphology of dalmanitids, although having a conterminant hypostome, is different from that of Asaphus, being more flattened, with elevated eyes, a different glabellar lobation and so on. Rather shallow burrowing or ploughing is more likely in dalmanitids. Despite their common occurrence as body fossils, there are no trilobite-related traces known from the Praha and Zlíchov formations. The probability of their preservation is very low because of taphonomic conditions (R. Mikuláš, pers. comm.). The number of complete dalmanitids is too few to enable a study of the occurrence and variation of exoskeletal configurations in individual beds.

\section{Discussion and interpretation}

Dalmanitids are among those trilobites with a supposed predator-scavenger mode of life (Fortey \& Owens 1999a, b). All the observations made here accord generally with this interpretation. However, the morphology of Dalmanites and particularly that of Odontochile, is not what would be expected for active predators of relatively large mobile animals. In particular, the situation of the eyes does not facilitate the effective anterior vision necessary for active pursuit of prey. However, Clarkson (1966) clearly showed that the visual fields of some Wenlock dalmanitids do overlap at front and rear. There is also at least some degree of binocular vision in these areas. However, the visual field in Dalmanites forms a relatively narrow latitudinal belt, inclined very slightly upwards from the horizontal line.

We interpret this shape of visual field as effective more for the identifying the predators rather than for catching of the prey. As Bruton \& Haas (2003b, pp. 356-358) suggested for Phacops, the large schizochroal eyes, with their vertical files of lenses, may have functioned primarily as motion detectors, to identify the presence of enemies. On the other hand, Schoeneman (2007) has recently presented a new, detail analysis of the schizochroal eyes, presenting 
evidence, that this eye type was a neural superposition visual system, capable of producing a good overall image. The common traces of injuries described by Šnajdr (1987b) and Budil et al. (submitted) show that dalmanitids, even those of large size, were commonly attacked.

We consider all the characteristic morphological features of late Silurian-early Devonian dalmanitids as adaptations for rather shallow burrowing or ploughing in the superficial layers of the sediment. The flattened body morphology with elevated eyes would have enabled the animal to see its surroundings even when partly buried in sediment (Thomas \& Lane 1984). The animals may have fed using a combination of grazing, scavenging and predation of small burrowing animals. The differences in general exoskeletal and hypostomal morphologies described here suggest some variations in life-mode and feeding strategy. The more primitive condition is seen in Dalmanites, which may have relied more on predation and/or have taken more mechanically robust prey.

The "odontochilid" morphology is characterized by: a generally flat body shape; longer genal spines, offering improved stability during the flexing of exoskeleton to burrow into the sea floor; larger, more elevated, but rather posteriorly placed eyes; a hypostome with smaller and denser fine denticles on the posterior doublure; a large, flat and multi-segmented pygidium. These may be adaptations for greater reliance on scavenging and/or grazing.

Shallow burrowing near the surface of the sediment is inferred, the thoracic and pygidial appendages being used to collect food and transport it towards the mouth in the manner suggested by Eldredge (1971). Stürmer \& Bergström (1973) suggested a raptorial mode of feeding in Devonian dalmanitids, but argued that this was probably combined with suction of material into a food groove, without true filtering. The vaulted "odontochilid" glabella, lying above the flat, wide hypostome, and surrounded by tightly embracing genal spines, invites a comparison with the filtering chamber inferred by Fortey \& Owens (1999a, b) for harpetids and trinucleids, and seen also in some aulacopleurids. Filter feeding was proposed for Phacops by Bruton \& Haas (2003a), and this interpretation represents an interesting alternative to the generally accepted concept of Fortey \& Owens (1999a, b). We do not consider filter feeding likely in dalmanitids, but suction into a food groove could have been very effective, especially on a soft, muddy sea-floor. Shallow burrowing in search of food could explain also the prevalence of straight and moderately flexed specimens among articulated remains, and the extreme rarity of enrolled specimens.

The "odontochilid" features discussed here appeared several times, and in several combinations, in independent evolutionary lineages of dalmanitids. The mosaic emer- gence of these features in dalmanitid evolution may thus reflect repeated, relatively minor, changes in feeding strategies in the evolutionary lineage. These morphological changes therefore do not constitute a robust basis for recognition of the Odontochilinae Šnajdr, 1985 as an independent subfamily.

\section{Acknowledgements}

The Czech Science Foundation - Grant Agency of the Czech Republic (GAČR) supported this contribution through Grant Project 205/04/P026 'The Lower Devonian dalmanitid trilobites of the Prague Basin'. The PALSIRP Foundation supported the early stages of the investigation in 2003. We thank J. Frýda, O. Fatka, $\breve{S}$. Manda and D.J. Holloway for very useful discussion, and the reviewers R.M. Owens and E.N.K. Clarkson for their valuable comments on the manuscript. The sketch-figures were drawn by M. Mazuch and by R. Šarič.

\section{References}

BARRANDE, J. 1852. Systême Silurien du centre de la Bohême. $1^{\text {ère }}$ partie. Recherches paléontologiques, vol. 1. Crustacés, Trilobites. 935 pp. Privately published, Prague \& Paris.

BARRANDE, J. 1872. Systême Silurien du centre de la Bohême. $1^{\text {ère }}$ partie. Recherches paléontologiques. Supplement au vol. 1. 648 pp. Privately published, Prague \& Paris.

BRÜNNICH, M.T. 1781. Beskrivelse over Trilobiten, en Dyreslaegt og dens Arten, med en nye Arts Aftegning. Nye Samling af det Kongelige Danske Videnskabers Selskabs Skrifter 1, 384-395.

BRONGNIART, A. 1822. Histoire naturelle des Crustacés fossils, sous les rapports zoologigique et géologique, savoir les Trilobites. Les Crustacés proprement dits par A.-G. Desmarest. 65 pp. Paris.

BRUTON, D.L. \& HAAS, W. 2003a. Making Phacops come alive. Special Papers in Palaeontology 70, 331-347.

BRUTON, D.L. \& HAAS, W. 2003b. The puzzling eye of Phacops. Special Papers in Palaeontology 70, 349-361.

Budil, P., Hörbinger, F. \& MENZEL, R. Submitted. Lower Devonian dalmanitid trilobites of the Prague Basin (Czech Republic). Transactions of the Royal Society of Edinburgh.

CAMPBELL, K.S.W. 1977. Trilobites of the Haragan, Bois d'Arc and Frisco Formations (Early Devonian), Arbuckle Mountains region, Oklahoma. Bulletin of the Oklahoma Geological Survey $123,1-139$.

Chatterton, B.D.E. \& Perry, D. 1983. Silicified odontopleurid trilobites from the MacKenzie Mountains. Palaeontographica Canadiana 1, 1-55.

Cherns, L., WheEley, J.R. \& KARIS, L. 2006. Tunneling trilobites: habitual infaunalism in an Ordovician carbonate seafloor. Geology 34, 657-660. DOI 10.1130/G22560.1

Clarkson, E.N.K. 1966. Schizochroal eyes and vision of some phacopid trilobites. Palaeontology 9, 464-487. 
CURTIS, N.J. \& LANE, P.D. 1998. The Llandovery trilobites of England and Wales. Part 2. Monograph of the Palaeontographical Society, London 152, 51-101.

DALMAN, J.W. 1827. Om Palaederna, eller sí kallade Trilobiterna. Kongliga Svenska Vetenskaps-Akademiens Handlingar 1826, 113-152, 226-294.

DEAN, W.T. 1960. The Silurian trilobite Dalmanites myops (König.). Palaeontology 2, 280.

DELO, D.M. 1935. A revision of the phacopid trilobites. Journal of Paleontology 9, 402-420.

Destombes, J. 1963. Quelques noveaux Phacopina (trilobites) de l'Ordovicien supérieur de l'Anti-Atlas (Maroc). Notes $d u$ Service Geologique du Maroc 23(172), 47-65.

El Chair, M., Hammann, W. \& Thiedig, F. 1985. Neue Trilobiten- und Graptolithenfunde aus den Tanezzuft-Schiefern (Llandovery, Silur) des Fezzan, Südwest-Libyen. Mitteilungen aus dem Geologisch-Paläontologische Institut der Universität Hamburg 59, 83-98.

EldREDGE, N. 1971. Patterns of cephalic musculature in the Phacopina (Trilobita) and their phylogenetic significance. Journal of Paleontology 45, 52-67.

FORTEY, R.A. \& OWENS, R.M. 1999a. Feeding habits in trilobites. Palaeontology 42(3), 429-465. DOI 10.1111/1475-4983.00080

FORTEY, R.A. \& OWENS, R.M. 1999b. The trilobite exoskeleton, 538-562. In SAVAZZI, E. (ed.) Functional morphology of the invertebrate skeleton. John Wiley and Sons Ltd., London.

HAWLE, I. \& CORDA, A.J.C. 1847. Prodrom einer Monographie der böhmischen Trilobiten. 176 pp. Prague.

HollowAY, D.J. 1981. Silurian dalmanitacean trilobites from North America, and the subfamilies Dalmanitinae and Synphorinae. Palaeontology 24, 695-731.

IVANTSOV, A.J. 1990. Svjaz morphologii gipostomy i sposoba pitania trilobitov roda Asaphus, 128-130. In BETEKHTINA, O.A. \& ZHURAVLEVA, I.T. (eds) Sreda $i$ zhizn'v geologicheskom proshlom. Trudy Instituta Geologii i Geofiziki imenji 60-letia Sojuza SSR. Nauka, Novosibirsk.

KAESLER, R.L. Ed. 1997. Treatise on invertebrate paleontology, Part O, Arthropoda 1, Trilobita. 535 pp. Geological Society of America \& University of Kansas Press, Lawrence, Boulder.

KÖNIG, C.E. 1825. Icones fossilium sectiles. 4 pp. London.

LESPÉRANCE, P.J. 1975. Stratigraphy and palaeontology of the Synphoriidae (Lower and Middle Devonian dalmanitacean trilobites). Journal of Palaeontology 49, 91-137.

LINDSTRÖM, G. 1885. Förteckning på Gotlands siluriska crustacéer. Öfversigt Kongliga Svenska Vetenskaps-Akademiens Förhandlingar 6, 37-100.

MaKsimova, Z.A. 1972. New Devonian trilobites of the Phacopoidea [Novye devonskie trilobity Phacopoidea]. Paleontologicheskij Zhurnal 14(1), 88-95.

MESLINGER, K. 1987. Fine structure of scorpion trichobothria
(Arachnida, Scorpiones). Zoomorphology 107, 49-57. DOI 10.1007/BF00312129

MORRIS, S.F. 1988. A review of British trilobites, including a synoptic revision of Salter's monograph. Monograph of the Palaeontographical Society 140(574), 1-316.

MURCHISON, R.I. 1839. The Silurian System, founded on geological researches in the counties of Salop, Hereford, Radnor, Montgomery, Caermarthen, Brecon, Pembroke, Monmouth, Gloucester, Worcester and Stafford; with descriptions of the coalfields and overlying formations. London.

PřIBYL, A. \& VANĚK, J. 1971. Phacopida Struve, 1959 (Trilobita) im böhmischen Silur und Devon. Acta Universitatis Carolinae, Geologica 1, 53-68.

RAMSKÖLD, L. 1985. Silurian phacopid and dalmanitid trilobites from Gotland. Stockholm Contributions in Geology 40(1), $1-62$.

REED, F.R.C. 1901. Woodwardian Museum notes: Salter's undescribed species, 3. Geological Magazine 4(8), 106-110.

RichteR, R., Richter, E. \& STRUVE, W. 1959. Suborder Phacopina Struve, nov., 461-462. In MoORE, R.C. (ed.) Treatise on invertebrate paleontology. Part O. Arthropoda 1. Geological Society of America \& University of Kansas Press, Boulder, Colorado \& Lawrence, Kansas.

SALTER, J.W. 1864. A monograph of the British trilobites from the Cambrian, Silurian and Devonian formations, part 1. 224 pp. Monograph of the Palaeontographical Society.

SANDFORD, A.C. \& HOLLOWAY, D.J. 2006. Early Silurian phacopide trilobites from central Victoria, Australia. Memoirs of Museum Victoria 63, 215-255.

SCHOENEMANN, B. 2007. Trilobite eyes and a new type of neural superposition eye in an ancient system. Palaeontographica, A, 281, 63-91.

ŠNAJDR, M. 1985. Bohemian representatives of the subfamily Odontochilinae subf. nov. Věstník Ústředního ústavu geologického 60, 165-169.

ŠNAJDR, M. 1987a. Reussiana, new name replacing Reussia Maksimova, 1972 (Trilobita). Věstník Ústředního ústavu geologického 62, 104.

ŠNAJDR, M. 1987b. Bohemian Lower Devonian Odontochilinae (Trilobita). Sborník geologických věd, Paleontologie 28, 9-60.

STÜRMER, W. \& BERGSTRÖM, J. 1973. New discoveries on trilobites by X-rays. Paläontologische Zeitschrift 47, 104-141.

ThOMAS, A.T. \& LANE, P.D. 1984. Autecology of Silurian trilobites, 55-69. In BASSETT, M.G. \& LAWSON, J.D. (eds) Autecology of Silurian organisms. Special Papers in Palaeontology 32.

VogDES, A.W. 1890. A bibliography of Palaeozoic Crustacea from 1698 to 1899, including a list of the North American species and a systematic arrangement of genera. Bulletin of the US Geological Survey 63, 1-177.

WELLER, S. 1907. The palaeontology of the Niagara Limestone in the Chicago area. The Trilobita. Bulletin of the Chicago Academy of Sciences 4, 163-281. 